\title{
Investigation of the effect of hydroalcoholic mumie extract on expression of osteoprotegerin (OPG) and receptor activator of nuclear factor kappa-B ligand (RANKL)
}

\author{
Yosra Azizpour ${ }^{1}$, Monireh Azizi $^{2}$, Khairollah Asadollahi ${ }^{3}$, Naser Abbasi ${ }^{4}$ Ali Aidy ${ }^{5}$, Elahe Karimi ${ }^{6}$ \\ 1. MSc of Epidemiology, Department of Epidemiology, Faculty of Health, Ilam University of Medical Sciences, Ilam, Iran. \\ ORCID ID: 0000-0002-3875-3871 \\ 2. Assistant Professor, Department of Anatomy, Faculty of Medicine, Ilam University of Medical Sciences, Ilam, Iran, \\ (Corresponding Author), Tel: 084-32235716, Email: azizi-m@medilam.ac.ir. ORCID ID: 0000-0003-3090-867X \\ 3. Professor, Department of Social Medicine, Faculty of Medicine, Ilam University of Medical Sciences, Ilam, Iran. ORCID \\ ID: 0000-0003-2797-2814 \\ 4. Associate Professor, Biotechnology and Medicinal Plants Research Center, Department of Pharmacology, Faculty of \\ Medicine, Ilam University of Medical Sciences, Ilam, Iran. ORCID ID: 0000-0003-4457-3997 \\ 5. MSc of Biochemistry, Biotechnology and Medicinal Plants Research Center, Department of Pharmacology, Faculty of \\ Medicine, Ilam University of Medical Sciences, Ilam, Iran. ORCID ID: 0000-0001-5624-4184 \\ 6. Assistant Professor, Biotechnology and Medicinal Plants Research Center, Department of Pharmacology, Faculty of \\ Medicine, Ilam University of Medical Sciences, Ilam, Iran. ORCID ID: 0000-0003-0482-1554
}

ABSTRACT

Background and Aim: Osteoporosis is one of the most common bone diseases that is caused by an imbalance between the activity of osteoblasts and osteoclasts. Osteoprotegerin (OPG) plays an active role in inhibiting osteoclasts by binding to the receptor activator of nuclear factor kappa-B ligand (RANKL). The balance in the OPG/RANKL ratio is important in bone remodeling. The current study investigated and compared the effects of mumie extract and chemical drugs on cell proliferation, expression of OPG and RANKL in MG63 cells.

Materials and Methods: The effects of 100, 200 and $300 \mu \mathrm{g} / \mathrm{ml}$ of mumie extract on cell proliferation, expression of OPG and RANKL in MG63 cells were investigated in experimental groups, positive and negative control groups. Data were analyzed by ANOVA test.

Results: Significant increases were observed in the proliferation of MG63 cells after exposure to 100 and $200 \mu \mathrm{g} / \mathrm{ml}$ concentrations of mumie extract. $200 \mu \mathrm{g} / \mathrm{ml}$ concentration of the extract significantly decreased the expression of RANKL and increased the expression of OPG. It also increased OPG/RANKL ratio significantly in the experimental groups, compared to those in the negative control groups. Although the effects of $100 \mu \mathrm{g} / \mathrm{ml}$ and $200 \mu \mathrm{g} / \mathrm{ml}$ concentrations were similar to each other, they showed no significant effects on the variables. $300 \mu \mathrm{g} / \mathrm{ml}$ concentration of the extract showed a reverse and insignificant effect.

Conclusion: $200 \mu \mathrm{g} / \mathrm{ml}$ concentration of mumie extract had a significant effect on the expression of two important factors in bone remodeling. Therefore, individuals susceptible to osteoporosis can use mumie extract as an alternative to chemical drugs.

Keywords: Mumie extract, Osteoporosis, Osteoblasts

Received: July 7, $2019 \quad$ Accepted: Oct 26, 2019

How to cite the article: Yosra Azizpour, Monireh Azizi, Khairollah Asadollahi, Naser Abbasi, Ali Aidy, Elahe Karimi. Investigation of the effect of hydroalcoholic mumie extract on expression of osteoprotegerin (OPG) and receptor activator of nuclear factor kappa-B ligand (RANKL). SJKU 2020: 24 (6): 120-129

Copyright (C) 2018 the Author (s). Published by Kurdistan University of Medical Sciences. This is an open access article distributed under the terms of the Creative Commons Attribution-Non Commercial License 4.0 (CCBY$\mathrm{NC}$ ), where it is permissible to download, share, remix, transform, and buildup the work provided it is properly cited. The work cannot be used commercially without permission from the journal. 


\title{
بررسى تأثير عصاره هيدروالكلى موميايى (Mumie) بر بيان استئوبروتكرين (OPG) و كيرنده فعال فاكتور هسته اى كايا بتا ليكاند (RANKL)
}

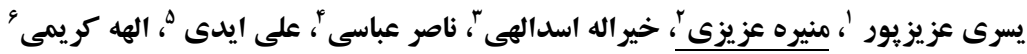

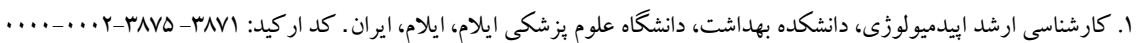

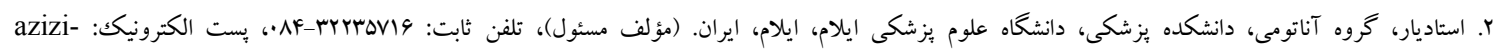

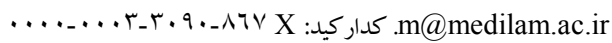

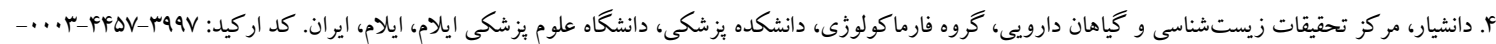 \\ ه. كارشناسى ارشد بيوشيمى، مركز تحقيقات زيستشناسى و گياهان دارويى ،گروه فارماكولوزى، دانشكده بز شكى، دانشكاه علوم يزشكى ايلام، ايلام، ايران. كد اركيد: ........ \\ (........-OAYF-FIAF

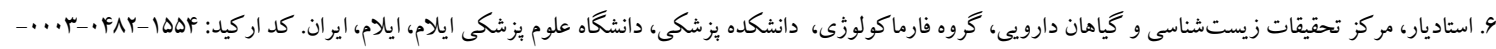

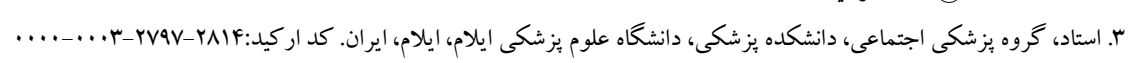
. 
ترابى نيز استفاده مىشود(9)؛ اما روشهاى ذكر شده بهطور يقين داراى عوارض جانبى براى بيماران هستند(• •). استفاده

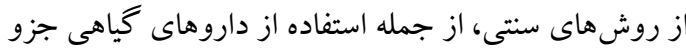
روشهايى است كه به لحاظ طبيعىبودن مىتوانند خطرات كمترى براى بدن داشته باشند، از جملهى اين مواد مىتوان ماده موميايى را نام برد. ماده موميايى در زبان هندى(Shilajit, ral-yahudi)، در زبان عربى(-Hajar) (ul-musa)، در زبان روسى(Myemu and mumie)، در زبان فارسى(Momiai-faqurul-yahud)، در زبان آلمانى(Mumie or salhumin)، در زبال زبان jews pitch, ,Asphalt, mineral pitch)(نخليسى Asphaltum (bitumen (punjabinum خوانده مىشود( (1)). موميايى در كوههاى دورين سرتاسر جهان به خصوص هيماليا به شكل عصاره جسبناكك از ميان سنگهاى رسوبى به آرامى نفوذ مى كند و داراى

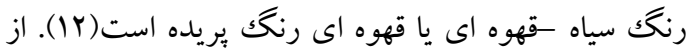

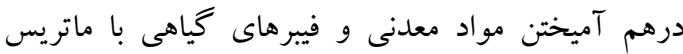

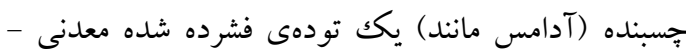

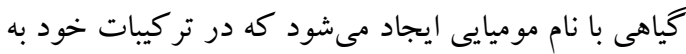
عنوان يكك ضد التهاب داراى عناصر كلسيم، منيزيم، آهن، فسفر، بتاسيم، سيليسيم، صمغ، رطوبت، نيتروزن، اسيد تانيكى، اسيد بنزوئيك، آدامس، آلبومينويد، گو گرد، آهن،

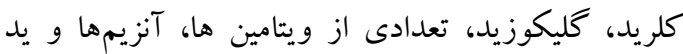

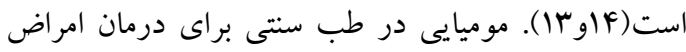
مختلف از جمله بيمارىهاى استخوانى استفاده مىشود(ه) . لذا در اين بزوهش تأثير عصاره هيدروالكلى ماده موميايى

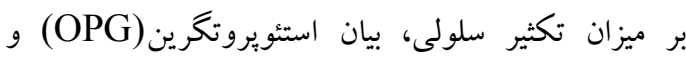
كيرنده فعال فاكتور هسته اي كايا بتا ليكاند) (RANKL) در سلولهاىMG63 در مقايسه با داروهاى شيميايى زولدرونيك اسيد (بيسففونات) و استراديول والرات بهنوان گروههاى كنترل مثبت مورد بررسى قرار گرفته
مقدمه

بيمارى بوكى استخوان با كاهش حجم توده استخوان و تغييرات در ساختار استخوان همراه است كه سبب افزايش خطر شكستخى به خصوص در ناحيه ستون فقرات و ران مى گردد( (1). در كاهش توده بهـ استخوانى توازن فعاليت بين سلولهاى استئوبلاست و استئو كلاست به هم خورده و ميزان فعاليت سلولهاى استئو كلاست افزايش مى ميابد(Y).

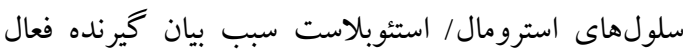
فاكتور هستهاى كايا بتا ليخاند) (RANKL) مىشوند. اتصال RANKL به گيرنده خود (RANK) در سطح سلولهاى استئوكلاست، سبب فعالشدن اين سلولها و شروع عمليات تخريب استخوان مى گردد. از طرف ديخر اتصال استئويروتخرين (OPG) بيان شده توسط سلولهاى

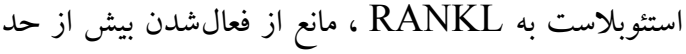
استئو كلاست مىشود. حفظ نسبت OPG/RANKL براى استحكام استخوان ضرورى است(r). يوكى استخوان مى تواند بهصورت اوليه و يا ثانويه باشد. نوع اوليه در افراد

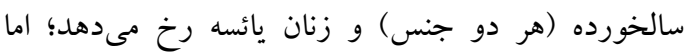
شرايط خاص بالينى باعث ايجاد يوكى استخوان ثانويه مى گردد و حتى مىتواند گروههاى جوان را نيز درگير نمايد(Y). شيوع بوكى و كاهش تراكم استخوان در ايران در زنان و مردان بالاى •ه سال به ترتيب •Vو •ه درصد ذكر لهر شده است، كه عمر مفيد از دست رفته به دليل اين بيمارى در ايران FF هزار سال بوده است (F)، دامنه شيوع اين بيمارى

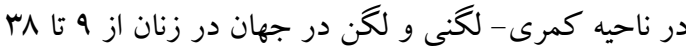
درصد و در مردان از اتا ^ درصد متغير بوده است(ه). تجربه شكستگى استخوان در زنان و مردان بالاى •ه سال مبتلا به اين بيمارى تقريبا به ترتيب •ه و Y Y درصد بوده است(9). بر آورد شده است كه سالانه حدود · · IV-Y بيليون دلار صرف هزينهاى بزشكى اين بيمارى مىشود(V). بيسففوناتها از جمله داروهاى مورد استفاده در درمان يو كى استخوان مىباشند(م). البته در زنان يائسه از هورمون مورد 
منتقل شده و درنهايت در دماى rV درجه سانتى گر اد و دى

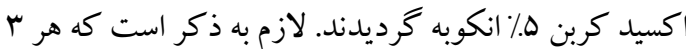
روز يك بار محيط كشت تعويض گرديد و در نهايت جداسازى سلولها از كف فلاسك و پاساز آنها با استفاده از 0.25\%.Trypsin_EDTA كروههاى آزمايش و كنترل: در اين بخش تعداد ...... سلول MG63 به داخل هريك از جاهك هاى بر بليت 99 خانه منتقل شد. شش گروه آزمايشى مورد بررسى قرار كرفت. در ب گروه آزمايشى عصاره هيدروالكلى موميايى،

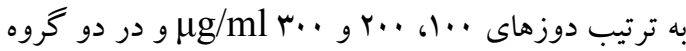
كنترل مثبت، داروهاى زولدرونيك اسيد و استراديول والرات با غلظت 1 mg/ml به جاهك هاى حاوى سلولهاى MG63 اضافه شد و در گروه كنترل منفى،

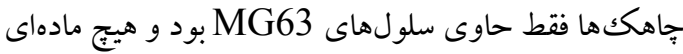
به آنها اضافه نشد. لازم به ذكر است كه در همه كروهاى آزمايشى، تعداد جاهك ها و سلولهاى MG63 موجود در لهال

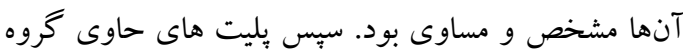

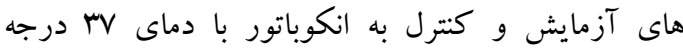
سانتى گر اد و 5\%

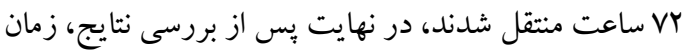
NA ساعت به عنوان زمان مناسب براى ادامه آزمايشهاى

$$
\text { مورد تائيد قرار كرفت (19). }
$$

تست حيات زيستى: ميزان تأثير عصاره موميايى (در (دردان كروههاى آزمايش) و زولدرونيك اسيد و استراديول والرات (در خروههاى كنترل مثبت) بر ميزان تكثير روني

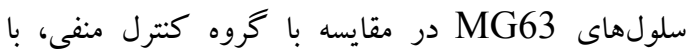
[3-(4, 5-dimethylthiazol-2-yl)-استفاده از تست كرون 2, 5-diphenyltetrazolium bromide] MTT Sigma Aldrich) سلولهاى استفاده شده در هر جاهك (..... (ه) سلول بود.

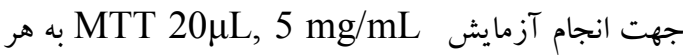

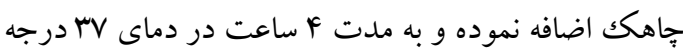

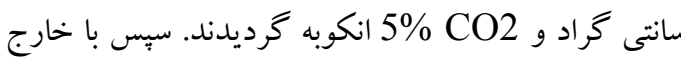

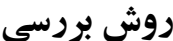
جمع آورى و عصاره گيرى: در اين مطالعه تجربى، ماده كياهى - معلنى موميايى با حالت جامد و رنغك قهوماى متمايل به سياه، يس از جمع آورى از كوههاى استان ايلام

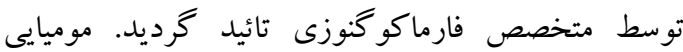

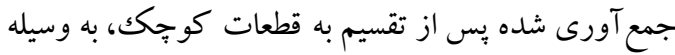

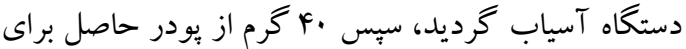
عصارهگيرى با روش استخراج ييوسته با دستخاه سو كسوله

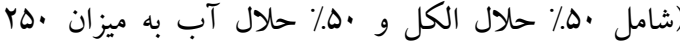
ميلىليتر ) جدا و عصاره گيرى در دماى •^درجه سانتى گراد انجام شد. جهت حذف آب و الكل، حلال به دست آمده IKA RV 10 دستخاه تبخير در خلأ (روتارى مدل 10

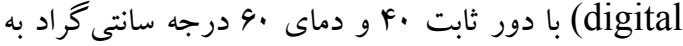
مدت •و دقيقه منتقل شد. سيس عصاره مورد نظر با انتقال به آون با دماى •م درجه به مدت دو ساعت خشك كرديد و به صورت يودر در ظروف شيشهاى دربسته در يخجال نغهدارى شد، در نهايت از · Fرم از ماده موميايى اوليه

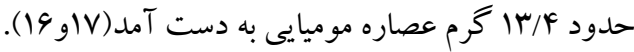
كشت سلولى: ردههاى سلول هاى شبه استئوبلاست انسانى

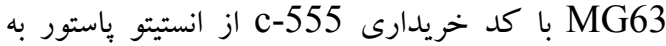
روش زير كشت داده شدند. ابتدا محيط كشت رويى سلولهاى خريدارى شده دور ريخته شد و جداسازى سلولها از كف فلاسك با اضافه نمودن 0.25\%

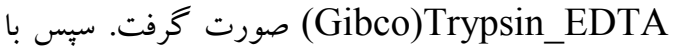
اضافه نمودن سرم جنين گوساله (FBS) • (Gibco) (1) خنثى سازى تريسين انجام شد. پِس از آن، سلولها در بـ

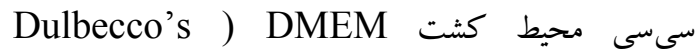
(Gibco)(modified Eagle medium به مدت ه دقيقه بادور . 10ا سانتريفيوز گرديدند. سبس با دور ريختن

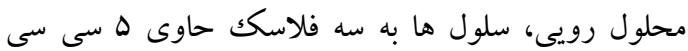

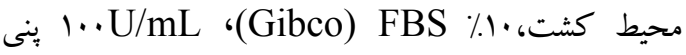

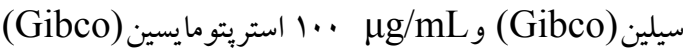


دادهها با استفاده از تست آمارى ANOVA انجام شد و هـ/• به عنوان سطح اختلاف معنى دار در نظر گرفته شد.

كافته ها

تست حيات زيستى: بر اساس نتايج به دست آمده از تست MTT Mg/ml r... شد؛ اما غلظت . MG63 r Mg/ml عصاره سبب كاهش معنىدار تكثير سلولها در مقايسه با گروه كنترل منفى

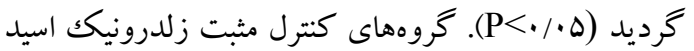
و استراديول والرات نيز سبب افزايش معنىدار تكثير سلولى

نسبت به كروه كنترل منفى شدند (ه (P> P) (نمودار (). بررسى بيان زمان استئويروتخرين (OPG) و گيرنده فعال فاكتور هسته ای كايا بتا ليخاند (sRANKL): همانطور

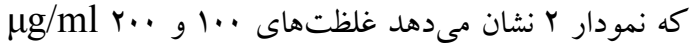
عصاره موميايى به ترتيب سبب افزايش غير معنىدار و افزايش معنىدار بيان استئوبروتخرين(OPG) در مقايسه با گروه كنترل منفى مى گردد كه در اين خصوص مشابه با معاب استر اديول والرات عمل نموده است (ه •/ P> P). درحالى كه

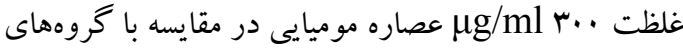
كنترل منفى و كنترل مثبت به ترتيب بهصورت غير معنىدار و معنىدار سبب كاهش بيان استئويروتخرين گرديده است.

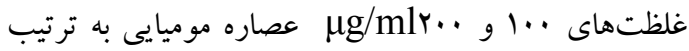
سبب كاهش غير معنىدار ( RANKL بيان در مقايسه با گرووه كنترل منفى شدهاند. در حالى كه اين كاهش بيان براى هر دو غلظت مذكور در مقايسه با گروه هاى كنترل مثبت، معنىدار

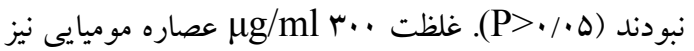
به صورت غير معنىدار سبب افزايش بيان RANKL نسبت

$$
\text { به گروه كنترل منفى شده بود (نمودارس). }
$$

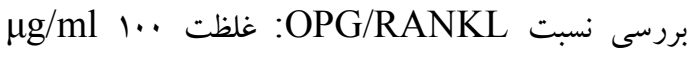
عصاره موميايى در مقايسه با گروههاى كنترل منفى و مثبت OPG/RANKL سبب افزايش غير معنىدار در نسبت
(Sigma DMSO نمودن مايع رويى، 1هL محلول (به جاهك ها اضافه شد و جهت مخلوط شدن محلول با نمونهها از دستگاه شيكر استفاده گرديد. سبس (Biotek- يليتها براى خوانش توسط دستگاه الايزا ELX 800)

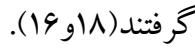
بررسى بيان زمانى استئويروتخرين (OPG) و گيرنده فعال فاكتور هسته ای كايا بتا ليكاند (Srank1): ابتدا محلول Human OPG استاندارد را توسط رقيق كننده استاندارد diluents Bioassay Technology Laboratory, رقيق نموده و از آن غلظتهاى ه/Dina تهيه كرديد. يس از قرار دادن يليت هاى جاهك دار حاوى غلظتهاى استاندارد و نمونهاى مورد آزمايش بر روى دستگاه شيكر، انكوبه نمودن در دماى MV درجه به مدت يكك ساعت انجام شد. سپس جاهك ها ها بار با محلول مخصوص شستشوى كيت شستشو داده شدند و در بايان ميزان بيانOPG بليتها با استفاده از دستكاه الايزا (Biotek- ELX 800) كرديد. همجنين جهت بررسى بيان SRANKL ابتدا محلول استانداردsRANKL توسط رقيق كننده استاندارد Human sRANKL diluents Bioassay Technology Laboratory, China

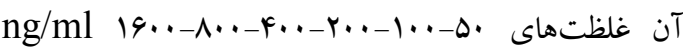
تهيه شد. پِيت هاى حاوى غلظتهاى استاندارد و نمونه هاى

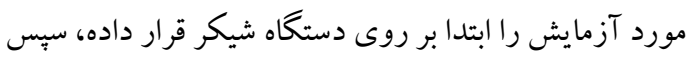
به انكوباتور با دماى MV درجه سانتى گراد به مدت يك

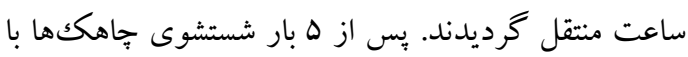
محلول مخصوص شستشوى كيت، ميزان بيان SRANKL

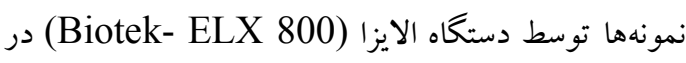
طول موج •ه\& نانومتر ارزيابى گرديد(19). روشهاى آمارى: در اين مطالعه آزمايشهاى مربوط به OPG و هANKL هر كدام ب بار تكرار كرديد. تجزيه و تحليل 
سبب كاهش غير معنىدار نسبت OPG/RANKL در مقايسه با همهى گروههاى كنترل مثبت و منفى گرديد

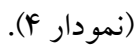

كرديد در حالى كه براى دوز .. افزايش نسبت فقط در مقايسه با خروه كنترل منفى معنىدار

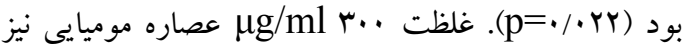

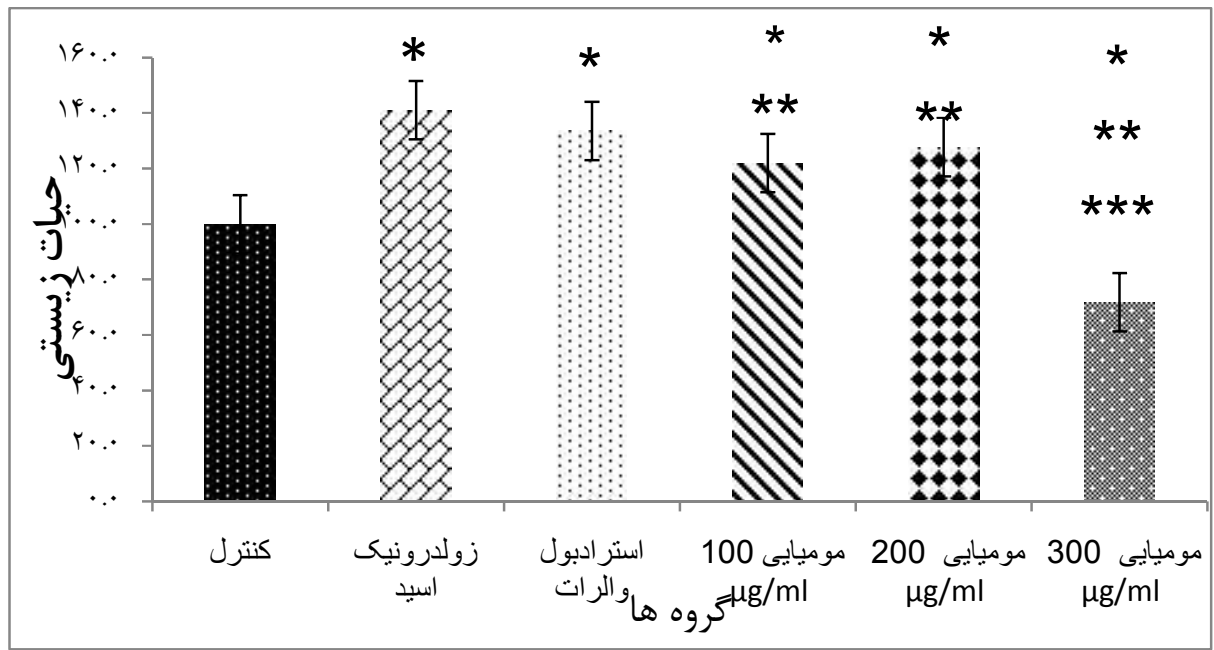

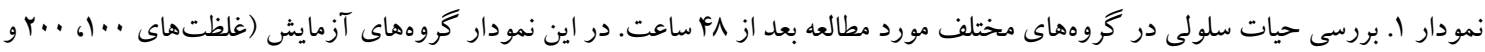

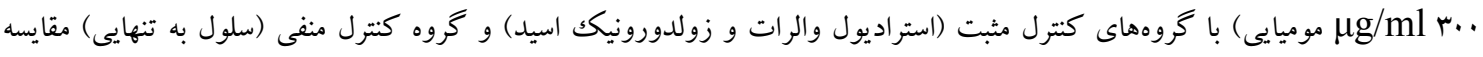

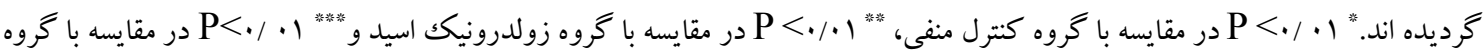
استر اديول والرات انجام شده است.

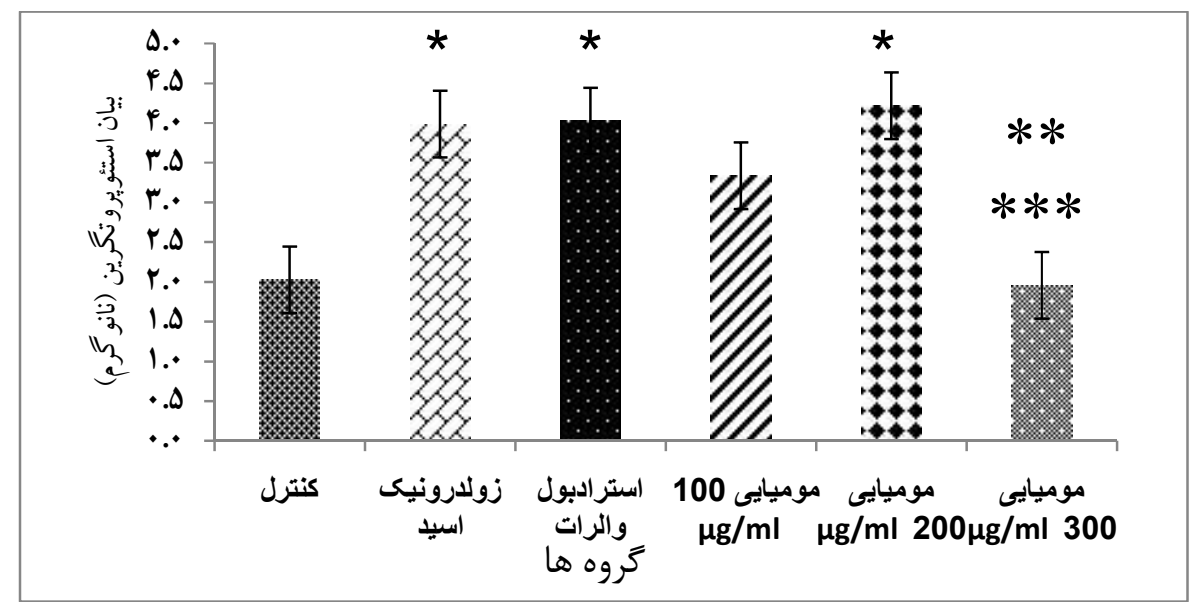

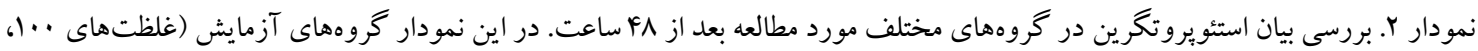

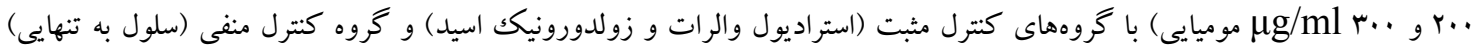

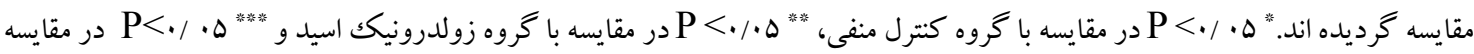
با گروه استراديول والرات انجام شده است. 


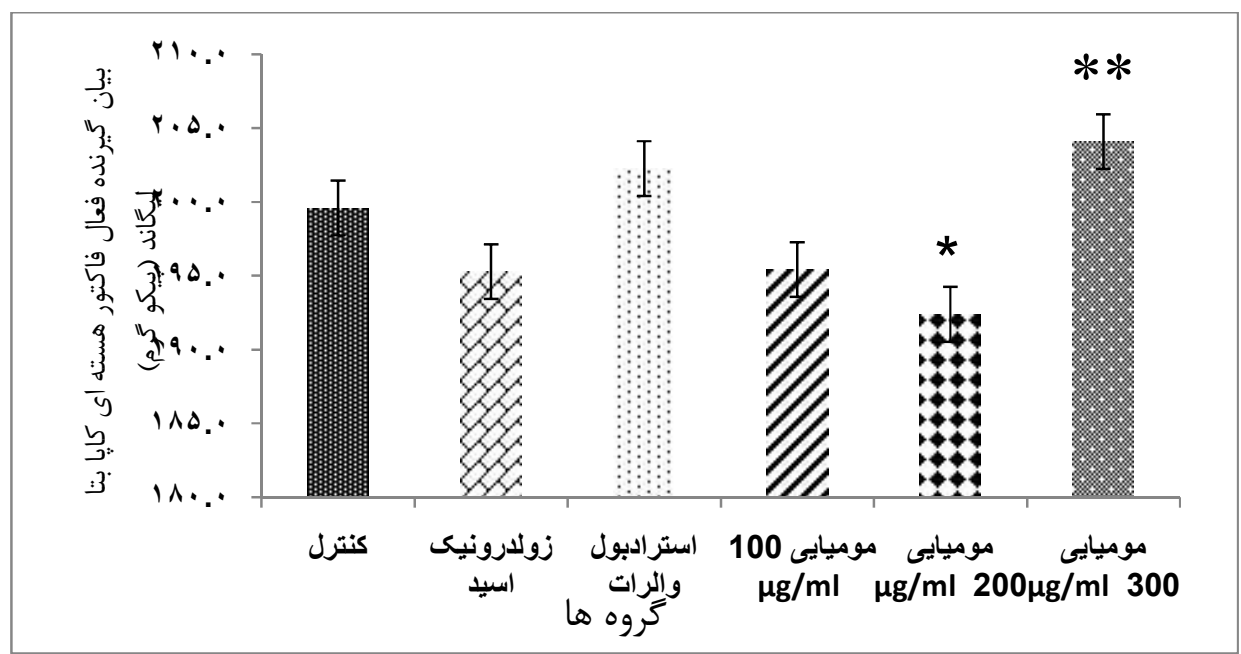

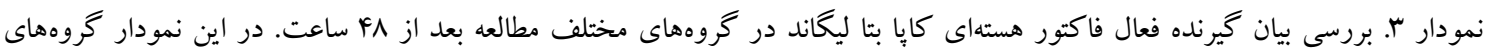

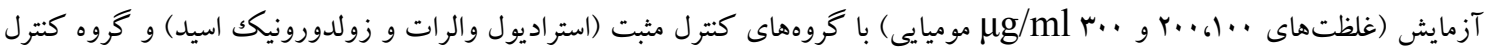

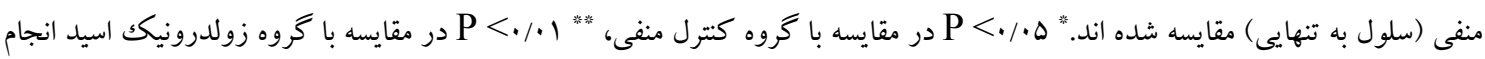
شده است.

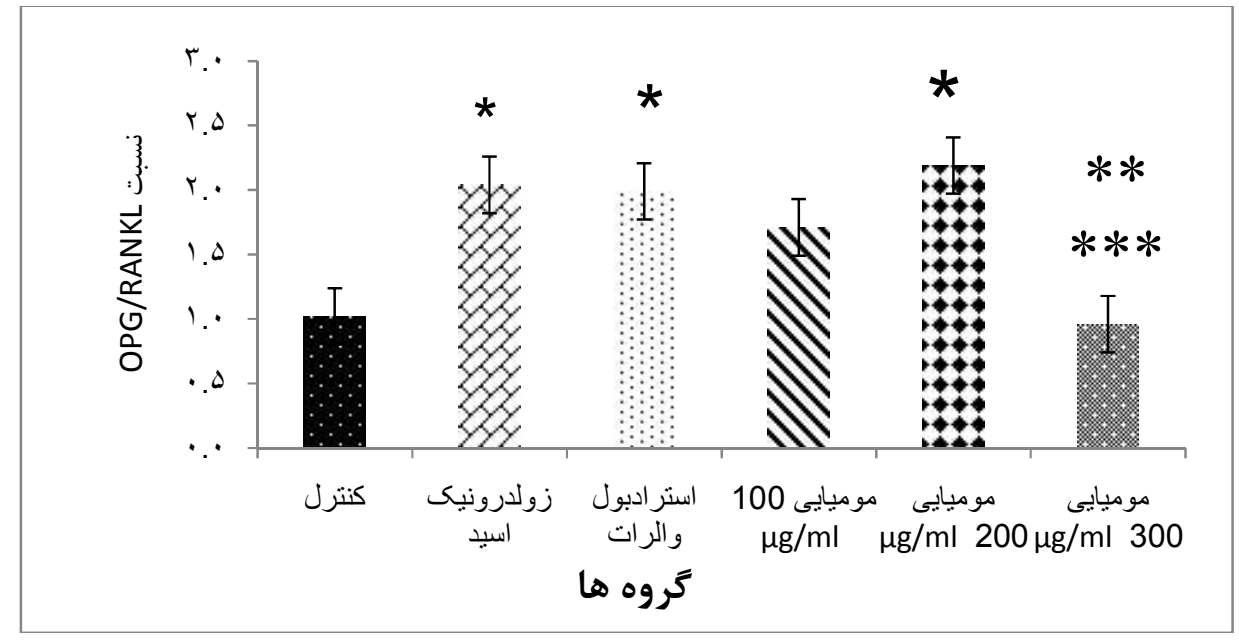

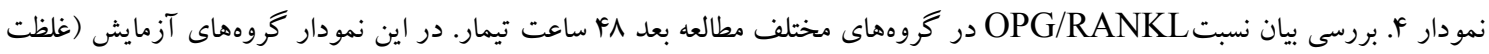

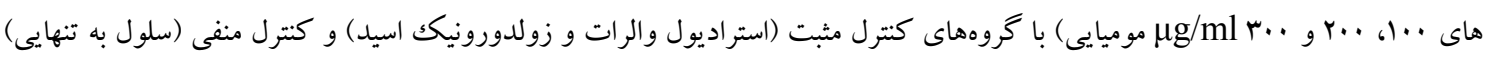

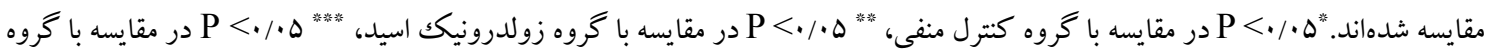
استر اديول والرات هست. تحريكك كننده تشكيل كلنى (CSF) سبب تحريكك و بحث تشكيل سلولهاى استئو كلاست مى گر دند و به عنوان عامل

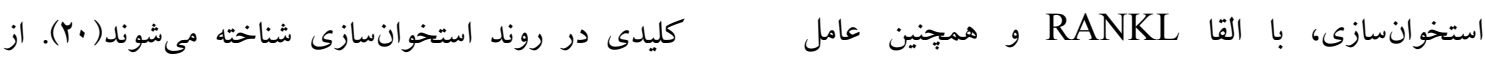


يُروهش حاضر را تائيد مىنمايد. لازم به ذكر است با افزايش نسبت OPG/RANKL عمل استخوانسازى بيشتر از جذب استخوان شده كه اين امر در افراد مبتلا به يوكى استخوان حائز اهميت مىباشد. زيرا در افراد مبتلا به يوكى به اله علت كاهش تكثير استئوبلاستها ميزان ترشح OPG نيز كاهش يافته، در نتيجه RANKL به گيرنده خود بر روى سلولهاى استئو كلاست (RANK) متصل گرديده و سبب لهب فعالشدن اين سلولها و در نتيجه افزايش ميزان استخوان خوارى مى گردد؛ بنابراين بدن توانايى كمترى براى ساخت

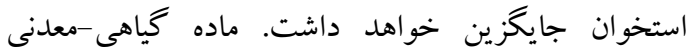
موميايى سبب افزايش تكثير استئوبلاست و به دنبال آن افزايش بيان OPG مى شود و بان افزايش نسبت OPG/RANKL كفه ترازو به سمت استخوان سازى

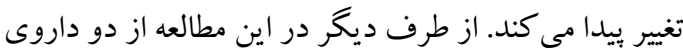

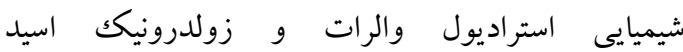
(بيسففونات) به عنوان گروه كنترل مثبت استفاده گرديد.

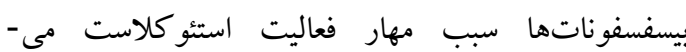
شوند(r)). در زنان يائسه به علت نبود استروزن فعاليت استئو كلاستها به ميزان قابل توجهى افزايشيافته و حجم توده استخوانى كاهش مىيابد. هورمون ترابى با مكانيسم مهار كردن فعاليت استئو كلاست از كاهش حجم استخوان

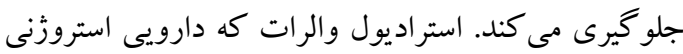
است نيز براى درمان يوكى استخوان در بعد از يائسكى زنان كاربرد دارد(YF). زولدرونيك اسيد نيز براى براى درمان استئويروز در زنان يائسه به كار مىرود د(Y).

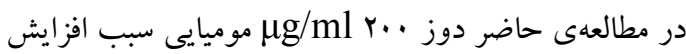

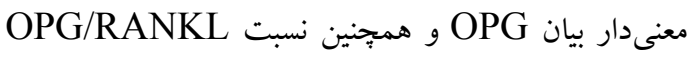
در مقايسه با گروه كنترل منفى شده است و داراى عملكرد مشابه با كروههاى كنترل مثبت است. لذا نتايج به دست كرو آمده

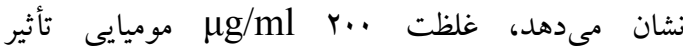
قابل توجهى بر بيان دو عامل مهم در بازسازى استخوان دارد و به نظر مىرسد افرادى كه در معرض يوكى استخوان قرار
طرف ديخر استئويروتخر ين بيان شده توسط استئوبلاستها / سلولهاى استرومال از طريق اتصال به RANKL از بيوند

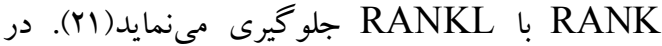

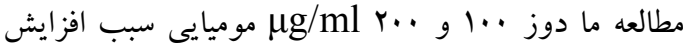
معنى دار تكثير سلولهاى استئوبلاست گرديد، همجنين دوز بg/ml r... نسبت OPG/RANKL در سلول هاى MG63 شد

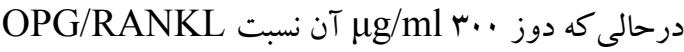
را بهصورت غير معنىدار كاهش داد. اين نتيجه بيانگر آن

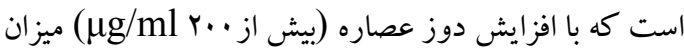
سميت عصاره بر روى سلولهاى استئوبلاست افزايش يافته و

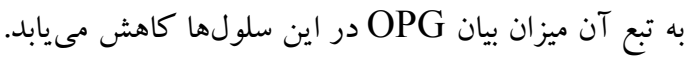
در تائيد اين نتيجه، مطالعه عباسى و همكاران (19.19) است كه نشان دادند غلظتهاى پايين لوتئولين كه فراوانترين فلاونوئيد موجود در موميايى مىباشد سبب كاهش و

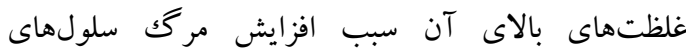

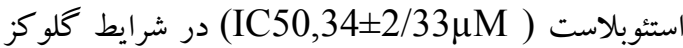

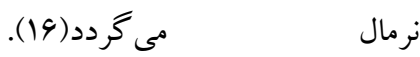

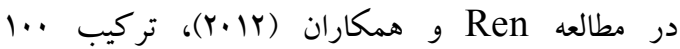
Mmol/L shuganjiangu بر سلولهاى MG63، سبب افزايش بيان

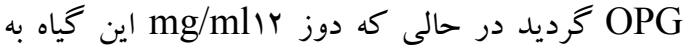
تنهايى سبب كاهش بيشتر بيان RANKL در مقايسه با

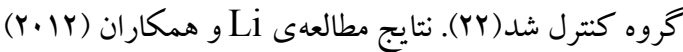
در مورد بررسى اثر اجيناكوسيد در بيان OPG و

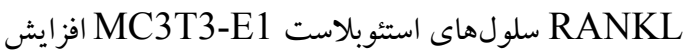

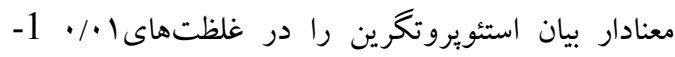

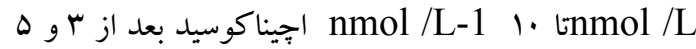
روز نسبت به گروه كنترل نشان داد. درحالى كه فقط غلظت-

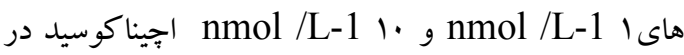
طى هـ روز سبب كاهش معنادار بيان RANKL

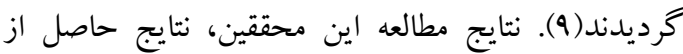




$$
\begin{aligned}
& \text { آزمايشهاى درونتى در حيوانات آزمايشگاهى و سبس در } \\
& \text { انسان ضرورى به نظر مىرسد. }
\end{aligned}
$$

$$
\begin{aligned}
& \text { تشكر و قدردانى } \\
& \text { نو يسند كان مقاله از حمايتهاى مالى دانشگاه علوم بز شكىى }
\end{aligned}
$$

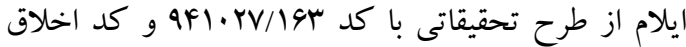

$$
\begin{aligned}
& \text { (ir.medilam.rec.1394.167) } \\
& \text { مىنمايند. لازم به ذكر است محل انجام آزمايشها، مركز } \\
& \text { تحقيقات زيستشناسى و گياهان دارويى دانشگاه علوم } \\
& \text { يز شكى ايلام بوده است. }
\end{aligned}
$$

$$
\begin{aligned}
& \text { نتيجه كيرى }
\end{aligned}
$$

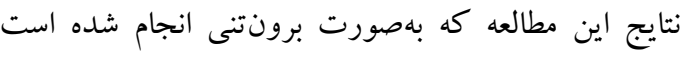

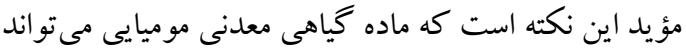

$$
\begin{aligned}
& \text { در درمان يوكى استخوان جايغزين مناسبى براى داروهاى } \\
& \text { شيميايى با عوارض جانبى بالاو مورد استفاده ى حال حاضر } \\
& \text { باشد؛ اما از آنجايى كه اين مطالعه فقط بهصورت برونتي بعنى } \\
& \text { انجام شده است، لذا جهت اثبات بيشتر اين مدعا، انجام }
\end{aligned}
$$

\section{References}

1.Shariatzadeh H, Modaghegh BS, Mirzaei A. The Effect of Dynamic Hyperextension Brace on Osteoporosis and Hyperkyphosis Reduction in Postmenopausal Osteoporotic Women. Arch Bone Jt Surg. 2017;5(3):181-5.

2.Johnell O. Advances in osteoporosis: better identification of risk factors can reduce morbidity and mortality. J Intern Med. 1996;239(4):299-304.

3.Boyce BF, Xing L. Biology of RANK, RANKL, and osteoprotegerin. Arthritis Res Ther. 2007;9 Suppl 1:S1.doi:10.1186/ar2165.

4.Hemmati F, Sarokhani D, Sayehmiri K, Motadayen M. Prevalence of Osteoporosis in Postmenopausal Women in Iran: A Systematic Review and Meta-Analysis. IJOGI. 2018;21(3):90-102.

5.Wade SW, Strader C, Fitzpatrick LA, Anthony MS, O'Malley CD. Estimating prevalence of osteoporosis: examples from industrialized countries. Arch Osteoporos 2014;9:182.

6.Shuid Nazrun A, Nizam Tzar M, Afian Mokhtar S, Naina Mohamed I. A systematic review of the outcomes of osteoporotic fracture patients after hospital discharge: morbidity, subsequent fractures, and mortality. Ther Clin Risk Manag. 2014;10:937-48.

7.Becker D, Kilgore ML, Morrisey MA. The societal burden of osteoporosis. Curr Rheumatol Rep. 2010;12(3):186-91.

8.Lucinda LM, Vieira BJ, Oliveira TT, Sá RC, Peters VM, Reis JE, et al. Evidences of osteoporosis improvement in Wistar rats treated with Ginkgo biloba extract: a histomorphometric study of mandible and femur. Fitoterapia. 2010;81(8):982-7.

9.Li F, Yang Y, Zhu P, Chen W, Qi D, Shi X, et al. Echinacoside promotes bone regeneration by increasing OPG/RANKL ratio in MC3T3-E1 cells. Fitoterapia. 2012;83(8):1443-50.

10.Leung PC, Siu WS. Herbal Treatment for Osteoporosis: A Current Review. J Tradit Complement Med. 2013;3(2):82-7.

11.Wilson E, Rajamanickam GV, Dubey GP, Klose P, Musial F, Saha FJ, et al. Review on shilajit used in traditional Indian medicine. J Ethnopharmacol. 2011;136(1):1-9.

12.Biswas TK, Pandit S ,Mondal S, Biswas SK, Jana U, Ghosh T, et al. Clinical evaluation of spermatogenic activity of processed Shilajit in oligospermia. Andrologia. 2010;42(1):48-56.

13.Park JS, Kim GY, Han K. The spermatogenic and ovogenic effects of chronically administered Shilajit to rats. J Ethnopharmacol. 2006;107(3):349-53. 
14.Goel RK, Banerjee RS, Acharya SB. Antiulcerogenic and antiinflammatory studies with Shilajit. J Ethnopharmacol. 1990;29(1):95-103.

15.Abbasi Teshnizi M, Akhavan Rezayat A, Zojaji SA, Zirak N, Javadi B, Nami SR, et al. Effect of Mummy on pain and wound healing of midian sternotomy in patients undergoing off-pump coronary artery bypass grafting surgery. The International Congress on Complementary and Alternative Medicine. 2015 Oct. 154-155.Mashhad.Iran.

16.Abbasi N, Azizpour Y, Azizi M, Karimi E, Aidy A, Asadollahi K. The effects of mumie extract on cell proliferation and enzyme expression of human osteoblast-like cells (MG63). JSRM. 2019;15(2):P1-6.

17.Izadpanah E, Hassanzadeh K, Yousefinejad V, Shahveisi K, Fatahi N, M.R M. Effect of selegiline on liver cholestasis induced by bile duct ligation in rat. SJKU. 2016;21(5):20-30.

18.Abbasi N, Khosravi A, Aidy A, Shafie iM. Biphasic Response to Luteolin in MG-63 Osteoblast-Like Cells under High Glucose-Induced Oxidative Stress. Iran J Med Sci. 2016;41(2):118-25.

19.Moloudi MR, Hassanzadeh K, Rouhani S, Zandi F, Ahmadi A, Khalwatian P, et al. Effect of chloroformic extract of Cichorium intybus on liver function tests and serum level of TNF- $\alpha$ in obstructive cholestasis in rat. SJKU. 2014;9(4):10-9.

20.Costa-Rodrigues J, Teixeira CA, Fernandes MH. Paracrine-mediated osteoclastogenesis by the osteosarcoma MG63 cell line: is RANKL/RANK signalling really important? Clin Exp Metastasis. 2011;28(6):505-14.

21.Liu JZ, Ji ZL, Chen SM. [The OPG/RANKL/RANK system and bone resorptive disease]. Sheng Wu Gong Cheng Xue Bao. 2003;19(6):655-60.

22.Ren Y, Han SY, Li PP. Effects of anastrozole combined with Shuganjiangu decoction on osteoblast-like cell proliferation, differentiation and OPG/RANKL mRNA expression. Chin J Cancer Res. 2012;24(2):151-6.

23.Sun J, Song F, Zhang W, Sexton BE, Windsor LJ. Effects of alendronate on human osteoblast-like MG63 cells and matrix metalloproteinases. Arch Oral Biol. 2012;57(6):72836.

24.Warren MP, Shu AR, Dominguez JE. Menopause and Hormone Replacement. Endotext [Internet].2015 Feb. Available from: https://www.ncbi.nlm.nih.gov/books/NBK279050./

25.Lambrinoudaki I, Vlachou S, Galapi F, Papadimitriou D, Papadias K. Once-yearly zoledronic acid in the prevention of osteoporotic bone fractures in postmenopausal women. Clin Interv Aging. 2008;3(3):445-51. 